\title{
IMPLEMENTASI PEMBELAJARAN PAI BERBASIS LINGKUNGAN SEKOLAH DI SMP NEGERI 16 MEDAN
}

\author{
Nurramidah Nasution* \\ Ali Imran Sinaga** \\ Salminawati***
}
*Mahasiswa Magister S2 PAI FITK UIN Sumatera Utara Medan **Dosen Magister S2 PAI FITK UIN Sumatera Utara Medan ***Dosen Magister S2 PAI FITK UIN Sumatera Utara Medan

\begin{abstract}
Abstrak
Tujuan penelitian ini adalah: 1) Bagaimana perencanaan pembelajaran yang dilakkan guru PAI di SMP negeri 16 Medan? 2) Bagaimana pelaksanaan pembelajaran PAI berbasis lingkungan sekolah yang dilaksanakan di SMP Negeri 16 Medan? 3) Bagaimana hasil belajar siswa pada mata pelajaran PAI berbasis lingkungan skeolah di SMP Negeri 16 Medan? 4) Apa perubahan positif pada lingkungan sekolah setelah pelaksanaan pemeblajaran PAI berbasis lingkungan skeolah di SMP Negri 16 Medan?. Metode penelitian menggunakan penelitian kualitatif, yaitu penelitian yang dilakukan secara alamiah dengan memanfaatkan peneliti sebagai instrument penelitian. Subjek penelitian ini adlah guru PAI, kepala sekolah, dan siswa SMP Negeri 16 Medan. Data diambil melalui observasi, dokumentasi, dan wawancara. Data dinanalisis berdasarkan reduksi data, penyajian data, dan penrikan kesimpulan. Hasil penelitin ini dapat disimpulkan sebagai berikut: 1) Perencanaan pembelajaran yang dilakukan oleh guru PAI sesuai dengan standar kurikulum. Guru PAI menyusun rencana pembelajaran berdasarkan visi dan misi sekolah, standar kompetensi, dan juga disusun berdasarkan pola pembelajaran yang menarik dan inovatif. 2) Pelaksanaan pembelajaran yang berlangusng menarik dan menyenangkan. siswa menunjukkan sikap antusias terhadap pembelajaran PAI yang dilaksanakan oleh guru. 3) Hasil belajar siswa meningkat setelah selesai pembelajaran PAI, dimana siswa dapat mengerjakan PR yang diberikan guru, UTS yang diberikan guru, dan UAS. Dimana siswa memperoleh nilai di atas KKM. 3) Peribahan yang terjadi di SMP Negeri 16 Medan adalah peribahan positif, dimana lingkungan sekolah menjadi lebih bersih dan rapi. Aktivitas warga sekolah menjadi lebih positif, dan senang dalam melestarikan lingkungan, hemat menggunakan air, dan memanfaatkan sumber daya dalam membuat lingkungan semakin indah.
\end{abstract}

Kata Kunci: Pembelajaran PAI, Lingkungan Sekolah 


\section{PENDAHULUAN}

Pendidikan merupakan kegiatan membudayakan manusia untuk dapat hidup berbudaya sesuai standar yang diterima oleh masyarakat (Neolaka \& Neolaka, 2017:2). Pendidikan juga dapat diartikan sebagai usaha sadar dan terencana untuk mewujudkan suasana belajar dan proses pembelajaran agar peserta didik secara aktif dapat mengembangkan potensi dirinya untuk memiliki kekuatan spiritual keagamaan, penendalian diri, kepribadian, kecerdasan, akhlak mulia, serta keterampilan yang berguna bagi dirinya, masyarakat, bangsa dan Negara (UU Sisdiknas No. 20 tahun 2003).

Pendidikan sebagai kegiatan untuk membuat manusia hidup berbudaya merupakan kegiatan yang dibutuhkan oleh setiap manusia sebagai makhluk yang diciptakan sebagai "khalifah fi al-ardh" [khalifah di muka bumi] yang bertugas untuk mengelola, memberdayakan, dan melestarikan segala sumber daya yang ada untuk kemaslahatan bagi alam semesta. Oleh karena itu, proses pendidikan hendaknya dilakukan dengan sebaik-baiknya. Pemilihan strategi pembelajaran dalam hal ini menjadi salah satu hal yang terpenting yang harus diperhatikan oleh guru guna mewujudkan proses pembelajaran yang bersifat multiarah antar guru, siswa, dan lingkungan (Uno \& Muhammad, 2015:4).

Strategi pembelajaran yang disusun oleh guru hendaknya didasari pada berbagai pertimbangan yang sesuai dengan situasi, kondisi, dan lingkungan yang akan dihadapi siswa. Umumnya, strategi pembelajaran didasarkan pada; 1) rumusan tujuan pemebelajaran yang ditetapkan; 2) analisis kebutuhan dan karakteristik peserta didik yang dihasilkan; 3) jenis materi pelajaran yang akan dikomunikasikan (Uno \& Muhammad, 2015:4).

Manusia merupakan bagian tak terpisahkan dari alam. Sebagai bagian dari alam, keberadaan manusia di alam adalah saling membutuhkan, saling terkait dengan makhluk yang lain. Manusia selain mempunyai peran sebagai bagian atau komponen alam, manusiia mempunyai peran dan posisi khusus diantara komponen alam dan makhluk ciptaan Tuhan yang lain yakni sebagai khalifah, wakil Tuhan dan pemimpin di bumi. Berikut adalah hubungan manusia dengan alam (Sukanda, 2011:17). Ada tiga hubungan antara manusia dengan lingkungan sekitar, yaitu hubungan keimanan dan peribadatan; hubungan pemanfaatan dan keberlanjutan; dan hubungan pemeliharaan untuk smeua makhluk (Sukanda, 2011:17). 
Hubungan keimanan dan peribadatan. Alam semesta berfungsi sebagai sarana bagi manusia untuk mengenal kebesaran dan kekuasaan Tuhan (beriman kepada Tuhan) melalui alam semesta, karena alam semesta adalah tanda atau ayat-ayat Allah. Manusia dilarang memperhamba alam dan dilarang menyembah kecuali hanya kepada Allah yang menciptakan alam.

Hubungan pemanfaatan yang berkelanjutan. Alam dengan segala sumberdayanya diciptakan Tuhan untuk memenuhi kebutuhan hidup manusia. Dalam memanfaatkan sumberdaya alam guna menunjang kehidupannya ini harus dilakukan secara wajar (tidak boleh berlebihan atau boros). Demikian pula tidak diperkenankan pemanfaatan sumberdaya alam yang hanya untuk memenuhi kebutuhan bagi gengerasi saat ini sementaar hak-hak pemanfaatan bagi generasi mendatang terabaikan. Manusia dilarang pula melakukan penyalahgunaan pemanfaatan dan atau perubahan alam dan sumberdaya alam untuk kepentingan tertentu sehingga hak pemanfaatannya bagi semua kehidupan menjadi berkurang atau hilang.

Hubungan pemeliharaan untuk semua makhluk. Manusia mempunyai kewajiban untuk memelihara alam untuk keberlangsungan kehidupan, tidak hanya bagi manusia saja akan tetapi bagi semua makhluk hidup yang lainnya. Tindakan manusia dalam pemanfaatan sumberdaya alam secara berlebihan dan mengabaikan asas pemeliharaan dan konservasi sehingga mengakibatkan terjadinya degradasi dan kerusakan lingkungan, merupakan perbuatan yang dilarang dan akan mendapatkan hukuman. Sebaliknya menusia yang mampu menjalankan peran pemeliharaan dan konservasi dengan baik, maka baginya tersedia balasan ganjaran dari Allah SWT.

Pertama, Manfaat yang bersifat Dunia (dunyawiyah) dari bercocok tanam adalah menghasilkan produksi (menyediakan bahan makanan). Karena dalam bercocok tanam, yang bisa mengambil manfaatnya, selain petani itu sendiri juga masyarakat dan negerinya. Lihatlah setiap orang mengkonsumsi hasil-hasil pertanian baik sayuran dan buah-buahan, bijiian maupun palawija yang kesemuanya merupakan kebutuhan mereka. Mereka rela mengeluarkan uang karena mereka butuh kepada hasil-hasil pertaniannya. Maka orang-orang yang bercocok tanam telah memberikan manfaat dengan menyediakan hal-hal yang dibutuhkan manusia. Sehingga hasil tanamannya menjadi manfaat untuk masyarakat dan memperbanyak kebaikan-kebaikannya. 
Bahkan manfaatnya bukan sebatas penyedian makanan bagi orang lain saja tetapi juga dengan bercocok tanam juga menjadikan lingkungan menjadi lebih sehat untuk manusia dimana udara menjadi segar karena tanaman menghasilkan oksigen yang diperlukan oleh manusia untuk proses pernafasan. Tanaman berupa pepohonan juga memberikan kerindangan bagi orang-orang yang berteduh di bawahnya, kesejukan bagi orang yang ada di sekitarnya. Tanaman juga menjadikan pemandangan alam yang enak dan indah dipandang. Lihatlah hamparan tanah yang dipenuhi oleh tanam-tanaman tentunya hati dibuat senang melihatnya, perasaan pun menjadi damai berada di dekatnya. Adapun bila melihat hamparan tanah yang kering dan gersang dari tanamantanaman tentu lah kita memperoleh perasaan yang sebaliknya.

Kedua, Manfaat yang bersifat agama (diniyyah) yaitu berupa pahala atau ganjaran. Sesungguhnya tanaman yang kita tanam apabila dimakan oleh manusia, binatang baik berupa burung ataupun yang lainnya meskipun satu biji saja, sesungguhnya itu adalah merupakan sedekah bagi penanamnya, sama saja apakah dia kehendaki ataupun tidak, bahkan seandainya ditakdirkan bahwa seseorang itu ketika menanamnya tidak memperdulikan perkara ini (perkara tentang apa yang dimakan dari tanamannya merupakan sedekah) kemudian apabila terjadi tanamannya dimakan maka itu tetap merupakan sedekah baginya. Sehingga dapat disimpulkan bahwa seorang muslim akan mendapat pahala dari hartanya yang dicuri, dirampas atau dirusak dengan syarat dia tetap bersabar dan menyerahkan segala sesuatunya kepada Allah Subhanahu Wa Ta'ala.

Syaikh Saliem bin 'Ied Al-Hilali hafizhohulloh menambahkan bahwa ketiga hadits tersebut menunjukkan perintah menanam pepohonan dan tumbuhan lainnya, serta keutamaan mengolah (membuat produktif) bumi dan hal itu termasuk amalan yang pahalanya tidak berhenti dengan kematian pelakunya. Hadits-hadits juga menunjukkan agar berusaha untuk memberi manfa' at kepada makhluk Allah Subhanahu Wa Ta'ala serta mempermudah urusan dan memenuhi seluruh kebutuhan mereka. Juga menunjukkan dibolehkannya mengembangkan profesi-profesi yang bermanfaat seperti (pertanian), perdagangan, perindustrian dan profesiprofesi lainnya serta merupakan bantahan terhadap orang-orang sufi yang sok zuhud. Adapun larangan yang ada terhadap hal-hal tersebut diartikan jika pekerjaan itu melalaikan seseorang dari urusan agama dan apabila dia menjadikan dunia sebagai tujuan utamanya serta tingkatan ilmunya yang tertinggi. Hal itu terjadi dalam kondisi memperbanyak harta dunia (Baqi, 1996: 120). 
Pembelajaran berbasis lingkungan dapat dilakukan untuk setiap mata pelajaran di sekolah, termasuk mata pelajaran Pendidikan Agama Islam (PAI). Pendidikan Agama Islam (PAI) dapat dipahami sebagai usaha sadar dan terencana untuk mengembangkan potensi peserta didik agar mengetahui, meyakini, mengamalkan, serta menyampaikan ajaran Islam dalam kehidupan sehari-hari. Pengertian PAI juga dapat dipahami dari keragaman makna pendidikan Islam. Ada tiga pengertian untuk memahami pendidikan Islam. Pertama, pendidikan (menurut) Islam, kedua pendidikan (agama) Islam, dan ketiga pendidikan (dalam) Islam (Muhaimin, 2001:98). Pada titik ini, pendidikan (agama) Islam adalah yang dapat dijadikan rujukan untuk memahami pendidikan agama Islam di samping pendidikan Islam. Dari perspektif pendidikan (agama) Islam, PAI dapat dipahami sebagai upaya mendidikkan agama Islam atau ajaran dan nilai-nilainya, agar menjadi way of life [pandangan hidup] dan sikap hidup seseorang (Siswanto, 2013:10). Pendidikan Agama Islam diharapkan menghasilkan manusia yang selalu berupaya menyempurnakan iman, taqwa, dan akhlak, serta aktif membangun peradaban dan keharmonisan kehidupan, khususnya dalam memajukan peradaban bangsa yang bermartabat. Manusia seperti itu diharapkan tangguh dalam menghadapi tantangan, hambatan, dan perubahan yang muncul dalam pergaulan masyarakat baik dalam lingkup lokal, nasional, regional maupun global.

Pendidik diharapkan dapat mengembangkan metode pembelajaran sesuai dengan standar kompetensi dan kompetensi dasar. Pencapaian seluruh kompetensi dasar perilaku terpuji dapat dilakukan tidak beraturan. Peran semua unsur sekolah orang tua siswa dan masyarakat sangat penting dalam mendukung keberhasilan pencapaian tujuan Pendidikan Agama Islam. Dalam buku pedoman Guru Pendidikan Agama Islam disebutkan bahwa proses belajar mengajar mengandung dua pengertian yaitu rentetan tahapan atau fase dalam mempelajari sesuatu, dan dapat pula berarti sebagai rentetan kegiatan perancangan oleh guru, pelaksanaan kegiatan sampai evaluasi hingga program tindak lanjut (Suryosubroto, 2010:22).

Keberhasilan suatu pembelajaran ditentukan oleh kompetensi guru dalam mempersiapkan, melaksanakan, mengevaluasi, serta memberikan feed back. Artinya, kualitas pembelajaran dengan guru sebagai pelaksana proses pembelajaran sangat menentukan tkesuksesan suatu pembelajaran PAI. Setidaknya ada 3 faktor yang mempengaruhi keberhasilan pembelajaran yakni faktor tujuan, faktor guru, dan faktor siswa atau 
peserta didik. Dalam literatur lain, komponen sistem pendidikan Islam setidaknya memuat tujuan pendidikan, kurikulum pendidikan, pendidik, peserta didik, metode pendidikan, dan evaluasi pendidikan. Guna mencapai tujuan pendidikan agama Islam, komponen di atas harus disetting dalam rangka mencapai tujuannya. Potensi peserta didik baik itu aspek kognitif, efektif, dan psikomotorik harus betul-betul tercapai. Sehingga peserta didik tahu apa itu Islam, terampil dalam melaksanakan syari'at Islam, dan yang terpenting, nilai-nilai ajaran Islam menginternal pada diri peserta didik dalam kehidupan sehari-hari di lingkungannya.

Namun, pembelajaran PAI di sekolah selama ini belum dapat diwujudkan sesuai dengan harapan di atas, berbagai permasalahan dan paradigma yang dimiliki masyarakat belum sesuai dengan hakikat pembelajaran PAI masih melekat dalam kehidupan masyarakat, diantaranya; 1) hasil pembelajaran PAI di sekolah masih dianggap belum sesuai dengan tujuan-tujuan PAI itu sendiri; 2) PAI dianggap mengalami kegagalan karena masih menitikberatkan pada hal yang bersifat formal dan hafalan, bukan pada pemaknaannya; 3) penyampaian materi pembelajaran oleh guru masih dianggap bersifat teori, bukan pada penciptaan suasana keagamaan; 4) pemebelajaran PAI dianggap mengalami masalah dalam metodologi karena masih didominasi oleh guru pada metode ceramah; 5) pembelajaran PAI dianggap hanya sekedar mengejar target pencapaian materi dari pada pencapaian kompetensi yang diharapkan. Hal ini nampaknya menjadi faktor beberapa sekolah memberikan jam yang terbatas pada guru PAI (Wiyani, 2016:19).

Munculnya paradigma masyarakat tentang kegiatan pembelajaran PAI di sekolah tentunya disebabkan oleh hasil pembelajaran yang belum sesuai dengan kehidupan sehari-hari masyarakat. Ditambah lagi dengan metode pembelajaran yang digunakan cenderung monoton dan didominasi oleh guru pada metode ceramah, sehingga siswa dianggap sebagai objek yang perlu diisi dengan berbagai teori yang harus dihafal dan diingat tanpa mempertimbangkan kebutuhan dan keterampilan peserta didik dalam kehidupan sehari-hari. Oleh karena itu, Pendidikan Agama Islam harus didorong untuk melakukan inovasi pembelajaran yang tidak hanya berkaitan dengan perangkat kurikulum dan manajemen, tetapi juga menyangkut dengan strategi dan taktik operasionalnya. Strategi dan taktik itu, menuntut perombakan model-model pendidikan sampai dengan institusi-institusinya, sehingga lebih efektif dan efisien, dalam arti pedagogis, sosiologis dan kultural dalam menunjukkan perannya (Sanaki, 2003:257). 


\section{METODOLOGI PENELITIAN}

Pada penelitian ini, latar penelitian yang saya pilih "Implementasi pembelajaran PAI berbasis lingkungan sekolah di SMP Negeri 16 Medan" adapun yang menjadi lokasi penelitian yang menjadi lokasi penelitian yang akan saya lakukan adalah di SMA Negeri 16 Medan. Waktu penelitian direncanakan akan berlangsung dari Desember 2017 sampai Maret 2018.

\section{HASIL PENELITIAN}

Perencanan Pembelajaran PAI Berbasis Lingkungan Sekolah yang Dibuat Oleh Guru PAI di SMP Negeri 16 Medan

Guru PAI sebagai salah satu tim yang ditugaskan di SMP Negeri 16 Medan tentunya memiliki tugas dan tanggung jawab dalam mensukseskan sekolah berbasis lingkungan hidup. Dalam kaitannya sebagai guru PAI, tentunya harus mengintegrasikan materi pelajaran dengan lingkungan hidup. Guru PAI sebagai salah satu personalia dalam sekolah Adiwiyata tentunya juga membuat Rencana Pelaksanaan Pembelajaran (RPP) yang memuat topic pembahasan, kompetensi inti, kompetensi dasar, tujuan, indikator, langkah-langkah pembelajaran, materi, sumber belajar, dan penilaian.

Hasil wawancara dengan guru PAI dalam membuat Rencana Pelaksanaan Pembelajaran beliau menyatakan bahwa:

"Materi pelajaran PAI disusun dengan mengaitkan materi tersebut kepada lingkungan hidup, misalnya materi thaharah adalah tentang hidup bersih. Alat yang dapat digunakan untuk bersih dalam beribadah adalah air yang suci dan mensucikan, atau debu yang suci. Oleh karena itu penting untuk menjaga kelestarian air, menggunakan air dengan hemat, menjaga lingkungan dari hal-hal yang bernajis dijadikan sebagai kegiatan pembelajaran PAI di SMP Negeri 16 Medan. Selain itu, pada materi Membaca Al-Qur'an sesuai dengan Tajwid dan Makhorijul khuruf dapat dilakukan dengan unsur-unsur yang sehat, seperti lidah gigi yang rapi, rongga mulut yang sehat, tenggorokan yang sehat, dan pernapasan yang bagus. Oleh karena itu rajin bersikat gigi, tidak merokok dan rajin berolah raga adalah cara yang dapat dilakukan untuk dapat membaca Al-Qur'an dengan baik selain dari banyak berlajar dan berlatih" (Wawancara dengan Dra. Muliana guru PAI SMP Negeri 16 Medan pada hari jum'at tanggal 09 Maret 2018 pukul 10.00 WIB 
di ruangan guru).

Berdasarkan uraian di atas, dapat dikatakan bahwa guru PAI berperan sesuai dengan kapasitas dan kewenangannya dalam mensukseskan sekolah Adiwiyata. Dimana guru PAI merencanakan pembelajaran PAI dengan mengaitkan materi-materi pelajaran yang dilakukan sekaligus mensukseskan kegiatan program sekolah Adiwiyata.

\section{Aktivitas Pembelajaran PAI Berbasis Lingkungan Sekolah di SMP Negeri 16 Medan}

Pembelajaran PAI di SMP Negeri 16 Medan dilaksanakan dengan menggunakan metode pembelajaran inquiry (penemuan), diskusi, pembelajaran berbasis proyek, dan pembelajaran berbasis masalah. Metode pembelajaran tersebut digunakan sesuai dengan materi pembelajaran dan tujuan pembelajaran yang akan dicapai. Hal ini sesuai dengan pernyataan guru PAI melalui wawancara sebagai berikut:

"Metode pembelajaran yang digunakan pada pembelajaran PAI di SMP Negeri 16 Medan sesuai dengan materi pelajaran dan tujuan pembelajaran yang akan dicapai. Metode pembelajaran dipilih berdasarkan kesesuaian materi dan kemampuan guru dan siswa dalam melaksanakannya, serta kesesuaian dengan tujuan pembelajaran. Misalnya tentang materi thoharah, materi yang akan memberikan pemahaman, keterampilan, dan sikap kepada siswa tentang hidup bersih. Sehingga tjuan yang akan dicapai adalah siswa mengenal alat-alat yang dapat digunakan dalam bersuci, dalam hal ini air, bagaimana air yang dapat digunakan untuk bersuci adalah air yang suci lagi dapat mensucikan, siswa dapat berwudhu dengan baik, juga siswa dapat menjaga kelestarian air. Maka metode yang digunakan adalah parktik, siswa diajak ke kamar mandi sambil menjelaskan bagaimana menggunakan air dengan baik, bagaimana berwudhu dengan baik. Siswa diminta satu per satu untuk mempraktikkannya setelah dicontohkan oleh guru sebelumnya. Selanjutnya teman-temannya diminta unutk memperhatikan sambil memberikan komentar. Dan pada akhirnya guru dan siswa sama-sama menyimpulkan pembelajaran. Pada pelaksanaannya, di bawah keran air diletakkan ember untuk menampung air bekas wudhu siswa. Sementara siswa diminta untuk secara perlahan-lahan membuka keran air dan berwudhu dengan baik." (Wawancara dengan Dra. Muliana, guru PAI SMP Negeri 16 Medan pada hari jum'at tanggal 09 Maret 2018 pukul 
10.00 WIB di ruangan guru).

\section{Hasil Belajar PAI yang Diperoleh Siswa Setelah Mengikuti Proses Pembelajaran PAI Berbasis Lingkungan Sekolah di SMP Negeri 16 Medan}

Hasil belajar PAI yang diperoleh siswa juga dapat dicapai sesuai dengan tujuan pembelajaran, dimana siswa dapat memperoleh pengetahuan, sikap, dan keterampilan yang baru setelah pembelajaran selesai dilakukan. Hal ini sesuai dengan penjelasan guru PAI melalui wawancara dengan guru PAI sebagai berikut:

"Setelah dilakukan pembelajaran saya menanyakan kepada siswa apakah materi pelajaran sudah dipahami, adakah materipelajaran yang belum dipahami, kemudian diberikan tugas yang akan dikerjakan di rumah (PR). Kemudian juga saya mengamati perubahan yang terjadi pada siswa. Kemudian juga diberikan MID dan UAs sesuai dengan jadwal yang ditetapkan sekolah. Melalui PR, MID dan UAS yang diberikan kepad siswa juga dapat sesuai dengan yang diharapkan, yaitu siswa memperoleh nilai sesuai dengan KKM" (Wawancara dengan Dra. Muliana, guru PAI SMP Negeri 16 Medan pada hari Jum'at tanggal 09 Maret 2018 pukul 10.00 WIB di ruangan guru).

Berdasarkan uraian di atas, dapat diketahui bahwa hasil belajar yang diperoleh siswa mencapai Kriteria Ketuntasan Minimal (KKM), dan juga dapat memiliki perubahan pada pemahaman, sikap, dan keterampilan yang diharapkan.

\section{Perubahan Positif yang Terjadi Pada Lingkungan Sekolah Adiwiyata Melalui Proses Pembelajaran PAI Berbasis Lingkungan Sekolah di SMP Negeri 16 Medan}

Keberhasilan kurikulum Pendidikan Agama Islam berbasis lingkungan pada sekolah Adiwiyata SMP Negeri 16 Medan sudah baik dengan tingkat keberhasilan berdasarkan hasil observasi kelas tujuh mencapai 90\% kelas delapan 92,5\%, dan kelas sembilan mencapai 95\% partisipasi siswa sangat tinggi dalam melaksanakan semua program yang sudah dibuat sekolah tetapi perlu ditingkatkan.terutama tempat ibadah dengan sarana yang lebih baik harus selalu dijaga kebersihannya.

Warga sekolah merupakan bagian dari segala hal yang ada dalam lingkungan sekolah antara manusia dengan segala zat, unsur, dan keadaan yang ada dalam lingkungan hidup terdapat hubungan timbal- 
balik sehingga membentuk suatu ekosistem. Hubungan kepedulian siswa terhadap lingkungan perlu dilakukan terus menerus, dibutuhkan adanya penjagaan yang lebih intensif dengan diharapkan siswa agar lebih perduli terhadap lingkungan sekitarnya. Hubungan ini dapat dilihat dari tingkat keberhasilan bahwa dia mencintai lingkungan merupakan indikator bentuk ketaqwaan anak atau guru kepada Tuhan Yang Maha Esa. Dengan cinta tanaman perduli lingkungan kalau dia hidup bersih berarti sudah mengamalkan agamanya baik dari hadis tidak hanya sekedar salat, puasa menegakkan salat sebagai bukti dia harus bersih.Tingkat keberhasilan kurikulum berbasis lingkungan pada sekolah Adiwiyata, yaitu ada peningkatan dalam akademis salah satunya karena lingkungan yang nyaman, guru termotifasi dan bisa menggunakan sarana yang ada, setidaknya dalam peningkatan budaya mereka lebih peduli dengan keindahan kelas dan tanaman yang ada di sekitarnya. Keberhasilan program Adiwiyata sangatlah diharapkan untuk dapat dilaksanakan tidak hanya di lingkungan sekolah tetapi dimanapun kita tinggal sebagai wujud keperdulian pada alam sekitar.

Wawancara dengan kepala sekolah tentang perubahan positif yang dialami sekolah melalui pembelajaran PAI dijelaskan sebagai berikut:

"Pembebalajaran yang dilakukan guru mata pelajaran ditekankan pada aspek pembelerdayaan lingkungan, oleh karena itu setiap guru diharuskan untuk memanfaatkan lingkungan sekolah sebagai bahan kajian materi pembelajaran. Selain itu, guru juga disarankan untuk melakukan pembelajaran yang menarik dan menyenangkan sehingga dapat memebrikan manfaat positif bagi lingkungan sekolah. Termasuk dalam hal ini guru PAI, guru PAI telah melakukan pembelajaran swsuai dengan program skeolah Adiwiyata. Guru PAI memanfaatkan lingkungans ebagai bahan kajian pembelajaran dan mengajak siswa untuk melesestarikan lingkungan" (Wawancara dengan kepala sekolah SMP Negeri 16 Medan pada hari Kamis tanggal 22 Februari 2018 pukul 10.00 WIB di ruangan kepala sekolah).

\section{PEMBAHASAN}

\section{Perencanan Pembelajaran PAI Berbasis Lingkungan Sekolah yang Dibuat Oleh Guru PAI di SMP Negeri 16 Medan}

Sebagaimana indikator yang diamati dalam penelitian ini melalui observasi yang peneliti lakukan, dapat diketahui bahwa perencanaan 
yang berlangsung di SMP Negeri 16 Medan dilakukan dengan sangat baik, dengan skor total untuk enam indikator yang diobservasi sebesar 22 atau 91,66\%. Keenam indikator yang dimaksudkan adalah:

a. Tersusunnya Visi, misi dan tujuan yang memuat upaya pelestarian fungsi lingkungan dan/ atau, mencegah terjadinya pencemaran dan/ atau kerusakan lingkungan hidup.

SMP Negeri 16 Medan telah menyusun visi misi dan tujuan sekolah berisikan upaya pelestarian lingkungan. Dimana visi SMP Negeri 16 adalah: “Unggul dalam kualitas, berdasarkan Iman dan Taqwa serta berbasis lingkungan". Sedangkan Misi SMP Negeri 16 Medan adalah: 1) Menciptakan suasana kondusif bagi peningkatan iman dan taqwa. 2) Membentuk pribadi peserta didik yang berbudi pekerti cerdas, trampil dan terhindar dari narkoba. 3) Membentuk pribadi peserta didik yang jujur, berani dan santun dan bertanggungjawab. 4) Menciptakan sekolah yang berbudaya lingkungan.

Tujuan SMP Negeri 16 Medan adalah: 1) Menjadikan SMP Negeri 16 Medan sebagai sekolah yang beretika, bermoral dan berbudi pekeri yang baik 2) Memperoleh penetapan SNP dari SMP Potensial Menuju SMP berstandard Nasional. 3) Mengembangkan kurikulum berbasis lingkungan. 4) Mewujudkan sekolah yang asri, bersih, indah dan sejuk. 5) Memberi bekal dan menumbuhkan karakter kepada para siswa untuk dapat mencegah terjadinya pencemaran dan kerusakan lingkungan. 6) Memperoleh juara dalam bidang Lingkungan Hidup melalui Sekolah Adiwiyata dengan meningkatkan upaya perlindungan dan pengolahan lingkungan hidup. 7) Mengoptimalkan proses pembelajaran dengan pendekatan pembelajaran yang terpusat pada siswa (student centered learning), antara lain CTL, PAKEM, serta layanan bimbingan dan konseling. 8) Berprestasi dalam bidang akademik maupun non akademik. 9) Membentuk siswa yang berkarakter disiplin, bertanggungjawab dan mandiri serta cinta tanah air dan berwawasan lingkungan, yang di internalisasikan lewat kegiatan UKS, PASKIBRA, Green School, KIR, Kelompok Seni, Kelompok Olahraga, English Club, Tata Upacara Bendera, Kepramukaan dan Upacara rutin setiap hari senin. 10). Memberikan pelayanan kepada peserta didik yang ramah amal dan ramah lingkungan.

Oleh karena itu, dapat dikatakan bahwa SMP Negeri 16 Medan memiliki visi misi dan tujuan sekolah yang terintegrasi 
dengan kegiatan-kegiatan yang berbasis lingkungan sekolah. Kegiatan tersebut berupa pembelajaran di kelas sebagai kegiatan intrakurikuler, kegiatan di luar kelas sebagai kegiatan ekstrakurikuler, ataupunkegiatan yang sengaja deprogram dalam rangka melestarikan lingkungan.

b. Terinternalisasi (tahu dan paham) Visi, misi dan tujuan kepada semua warga sekolah.

Berdasarkan visi misi, dan tujuan sekolah yang dilaksanakan di SMP Negeri 16 Medan, maka dapat dibuktikan dengan keterlibatan semua civitas sekolah dalam mensukseskan kegiatan yang direncanakan sekolah sebagai bentuk pemahaman dan kemauan semua civitas sekolah terhadap visi misi dan tujuan sekolah.

c. Struktur kurikulum memuat pelestarian fungsi lingkungan, mencegah terjadinya pencemaran, dan kerusakan lingkungan hidup pada komponen mata pelajaran wajib, dan/ atau muatan lokal, dan/ atau pengembangan.

SMP Negeri 16 Medan juga memiliki struktur kurikulum yang terinternalisasi ke dalam kegiatan-kegiatan yang berbasis lingkugan. Dimana setiap mata pelajaran dilaksanakan dengan memanfaatkan sumber daya lingkungan sebagai media pembelajaran dan dikelola dalam proses pembelajaran untuk kelestarian lingkungan sekolah.

d. Adanya ketuntasan minimal belajar pada mata pelajaran wajib dan / atau muatan lokal yang terkait dengan pelestarian fungsi lingkungan, mencegah terjadinya pencemaran, dan/atau kerusakan lingkungan hidup.

SMP Negeri 16 Medan juga memiliki criteria ketuntasan minimal (KKM) dalam belajar. Dimana untuk mata pelajaran agama ditetapkan sebesar 85, dan untuk mata pelajaran sosial lainnya ditetapkan 75, dan untuk mata pelajaran yang bersifat sains ditetapkan 70 .

e. Sekolah memiliki anggaran untuk upaya perlindungan dan pengelolaan lingkungan hidup sebesar $20 \%$ dari total anggaran sekolah.

SMP Negeri 16 Medan juga menganggagrkan 20\% dari total anggaran skeolah untuk mensukseskan program adiwiyata di SMP Negri 16 Medan.

1) Anggaran sekolah dialokasikan secara proporsional untuk kegiatan: (1) kesiswaan, (2) kurikulum dan kegiatan peningkatan 
kapasitas pendidikan dan kependidikan, dan (3) budaya dan lingkungan sekolah peningkatan pengembangan.

Anggaran yang dialokasikan SMP Negeri 16 Medan juga dimanfaatkan untuk pemberdayaan kegiatan kesiswaan, kurikulum dan kegiatan sekolah, peningkatan dan kapasistas pendidikan dan tenaga kependidikan, serta meningkatkan budaya lingkungan sekolah. Dimana smeuanya itu, berkontribusi tehadap lingkungan SMP negeri 16 Medan yang lebih bersih, rapi, indah dan lestari.

\section{Aktivitas Pembelajaran PAI Berbasis Lingkungan Sekolah di SMP Negeri 16 Medan}

Sebagaimana indikator yang diamati, hasil observasi yang peneliti lakukan, maka dapat diketahui bahwa aktivitas pembelajaran yang berlangsung di SMP Negeri 16 Medan dilakukan dengan sangat baik, dengan skor total untuk sepuluh indikator yang diobservasi sebesar 34 atau $85 \%$. Dengan dmeikian, dapat disimpulkan bahwa aktivitas pembeljaaran di SMP Negeri 16 Medan dalam menerapkan program sekolah Adiwiyata atau sekolah berbasis lingkungan sekolah berjalan sesuai dengan harapan. Dimana program yang dilaksanakan dapat berjalan dengan baik dan sesuai tujuan yang ditetapkan.

\section{Hasil Belajar PAI yang Diperoleh Siswa Setelah Mengikuti Proses Pembelajaran PAI Berbasis Lingkungan Sekolah di SMP Negeri 16 Medan}

Sebagaimana indikator yang diamati, dapat diketahui bahwa hasil belajar yang diperoleh siswa di SMP Negeri 16 Medan dilakukan dengan sangat baik, dengan skor total untuk empat indikator yang diobservasi sebesar 15 atau 93,75\%.

Berdasarkan observasi dan wawancara yang telah diuraikan tentang hasil belajar siswa pada materi PAI di SMP Negeri 16 Medan menunjukkan bahwa siswa sudah mengalami perubahan positif setelah mengikuti pembelajaran PAI. Dimana 85\% siswa sudah paham materi pada akhir pembelajaran, dan siswa sudah dapat mengejakan PR yang diberikan siswa, pada saat UTS dan UAS siswa juga memperoleh nilai di atas KKM. Oleh karena itu, dapat disimpulkan bahwa pembelajaran PAI berbasis lingkungan sekolah dapat memebrikan perubahan positif pada pemahaman dan pengamalan siswa di SMP Negeri 16 Medan tentang ajaran Islam dan lingkungan hidup. 


\section{Perubahan Positif yang Terjadi Pada Lingkungan Sekolah Adiwiyata Melalui Proses Pembelajaran PAI Berbasis Lingkungan Sekolah di SMP Negeri 16 Medan}

Kantin di SMP Negeri 16 Medan juga memberikan pelayanan yang ramah lingkungan. Kantin menjual makanan yang sehat, tanpa pengawet dan tanpa pewarna. Sebagaimana indikator yang diamati di atas, maka dapat diketahui bahwa perubahan positif diperoleh siswa di SMP Negeri 16 Medan adalah sangat baik, dengan skor total untuk empat indikator yang diobservasi sebesar 65 atau 95,58\%.

\section{SIMPULAN}

Hasil penelitin ini dapat disimpulkan sebagai berikut:

1. Perencanaan pembelajaran yang dilakukan oleh guru PAI sesuai dengan standar kurikulum. Guru PAI menyusun rencana pembelajaran berdasarkan visi dan misi sekolah, standar kompetensi, dan juga disusun berdasarkan pola pembelajaran yang menarik dan inovatif. Dalam penyusunan RPP para guru di SMP Negeri 16 Medan menggunakan format sebagai berikut: a. Identitas Mata Pelajaran, b. Tujuan Pembelajaran, c. Materi Ajar, d. Metode pembelajaran, e. Kegiatan Pembelajaran (pendahuluan, inti, penutup), f. Penilaian, Sumber / Bahan / Alat. Sasaran dalam merencanakan pembelajaran di SMP Negeri 16 Medan: Pertama, prinsip penyusunan RPP yang meliputi: ilmiah, relevan, sistematis, konsisten, memadai, aktual, fleksibel, menyeluruht. Kedua, meliputi standar kompetensi, kompetensi dasar, indikator, materi pembelajaran, kegiatan pembelajaran, sumber/bahan/alat, alokasi waktu, dan penilaian. Untuk mendapatkan bahan ajar yang semakin berkualitas, setiap tahun SMP Negeri 16 Medan melakukan evaluasi penyusunan bahan ajar yang teknisnya dilakukan secara kolaborasi antar guru mapel, guru mapel senior, tim pengembang kurikulum dan pengawas mata pelajaran dari dinas pendidikan. Adapun sasaran evaluasi meliputi konten (kebenaran dan keselarasan isi), Keluasan dan kedalaman materi, ketercernaan materi, penggunaan bahasa, performance (perwajahan,ilustrasi), dan kelengkapan bahan ajar.

2. Pelaksanaan pembelajaran PAI di SMP Negeri 16 Medan berlangsung menarik dan menyenangkan. Siswa menunjukkan sikap antusias terhadap pembelajaran PAI yang dilaksanakan oleh guru. Guru menggunakan metode pembelajaran diskusi, 
pengamatan, praktik, dan bermain peran. Setiap pembelajaran yang dilaksanakan didasarkan pada upaya pelestarian lingkungan. Pada materi wudhu misalnya, siswa diminta untuk mempraktikkan tata cara berwudhu di kamar mandi. Sementara guru meminta siswa untuk heman menggunakan air. Dimana pada setiap keran air diletakkan dibawahnya ember untuk menampung bekas air wudhu siswa, kemudian bekas air wudhu tersebt dimanfaatkan untuk menyiram tanaman.

3. Hasil belajar siswa meningkat setelah selesai pembelajaran PAI, dimana siswa dapat mengerjakan PR yang diberikan guru dengan baik, UTS yang diberikan guru dapat diikuti siswa dengan baik dan memeproleh nilai yang baik, dan UAS yang diberikan guru dapat diikuti siswa dan memeproleh nilai yang baik. Dimana siswa memperoleh nilai di atas KKM. Pada perilaku, siswa menganut motto LISAMBIL [lihat sampah ambil]. Dimana setiap siswa melihat sampah langsung mengambilnya dan membuangnya pada tempat yang disediakan.

4. Perubahan yang terjadi di SMP Negeri 16 Medan adalah perubahan positif, dimana lingkungan sekolah menjadi lebih bersih dan rapi. Aktivitas warga sekolah menjadi lebih positif, dan senang dalam melestarikan lingkungan, hemat menggunakan air, dan memanfaatkan sumber daya dalam membuat lingkungan semakin indah.

\section{SARAN}

Berdasarkan hasil penelitian di atas, dapat disarankan beberapa hal untuk mendapatkan hasil yang lebih optimal pada perkembangan selanjutnya. Adapun beberapa hal yang perlu disarankan adalah:

1. Kepada kepala sekolah, hendaknya dapat memenuhi berbagai sarana dan prasarana yang dapat menunjang pembelajaran berbasis lingkungan di SMP Negeri 16 Medan.

2. Kepada guru PAI agar kiranya dapat meningkatkan inovasi-inovasi dalam mengelola pembelajaran PAI, sehingga kegiatan pembelajaran PAI dapat semakin menarik dan menyenangkan.

3. Kepada siswa agar kiranya semakin meningkatkan motivasi belajar dan aktivitas belajaranya.

4. Kepada semua civitas sekolah agar kiranya dapat bersama-sama menjaga dan melestarikan lingkugan sekolah. 
5. Kepada lembaga pendidikan lain yang belum menerapkan kurikulum sekolah berbasis lingkungan, agar kiranya dapat mencontoh SMPNegeri 16 Medan dalam mengelola lingkungan, seperti menghemat energy air dan listrik, menerapkan motto LISAMBIL (lihat sampah ambil], melaksanakan kajuan-kajian keagamaan rutin setiap jum'at pagi. Dan memberdayakan kegiatan ekstrakurikuler dalam melestarikan lingkungan.

6. Kepada peneliti selanjutnya, agar kiranya dapat meneliti tentang sekolah adiwiyata, atau pembelajaran berbasis lingkungan sekolah melalui pembelajaran mata pelajaran yang berbeda, misalnya pelajaran biologi, pelajaran kewarganegaraan, dan lain sebagainya.

\section{DAFTAR Pustaka}

Abdullah, Abi Muhammad Ibn Ahmad al-Ansari al-Qurtubi, (1967) Jami Al-Ahkam Al-Qur"an. Mesir: Darul Kutub.

Abi Abdullah Muhammad Ibn Ahmad al-Ansari al-Qurtubi, (1967) Jami Al-Ahkam Al-Qur"an, (Mesir: Darul Kutub.

Al-Anwari, Amiril Mukmini. Strategi Pembentukan Karakter Peduli Lingkungan di Sekolah Adiwiyata Mandiri. Ta'dib, Vol. XIX, No. 02. (November 2014): 227-252.

Al-Bukhori, Abu Abdillah Muhammad bin Isma'il, Shahihul Bukhari jilid 3. (Beirut: Darul Fikr, 1415).

Al-Faraj, Abi, Jamaluddin Abdurrahman Ibn Ali Ibn Muhammad Al Jauzi, (1994) Zadul Masir Fi 'Iilmi Tafsir. Libanon: Darrul Kutb..

Andang, (2014) Keijakan Kurikulum Reorientasi Pendidikan Nasional Melalui Implementasi Kurikulum 2013. Malang: UMM Press.

Arsyad, Azhar. (2016) Media Pembelajaran. Jakarta: Rajawali Pers.

Aziz, Erwati. (2013) Upaya Pelestarian Lingkungan Hidup melalui Pendidikan Islam. Yogyakarta: Pustaka Pelajar.

Baqi, Muhammad Fuad Abdul . (19960 Al-Lu'lu' wal Marjan. (Surabaya: Bina Ilmu.

Basrowi \& Suwandi. (2008) Memahami Penelitian Kualitatif. Jakarta: Rineka Cipta

Borg, W.R., dan Gall, M.D. (1989) Educational Research: An Introduction. London: Longman, Inc.

Bungin, B. (2011) Metode Penelitian Kuantitatif; Komunikasi, Ekonomi dan Kebijakan Publik serta Ilmu-ilmu Sosial Lainnya. Jakarta: Kencana. 
Departemen Pendidikan Nasional, (2008) Kamus Besar Bahasa Indonesia Pusat Bahasa,: Jakarta: Gramedia Pustaka Utama.

Khaeruddin, et.al., (20070 Kurikulum Tingkat Satuan Pendidikan (KTSP) Konsep dan Implementasinya di Sekolah. Jogjakarta: Pilar Media.

Majid, Abdul. (20060 Pendidikan Agama Islam Berbasis Kompetensi: Konsep dan Implementasi Kurikulum 2003. Bandung: Rosda Karya.

Mappiare, A. (20060 Kamus Istilah Konseling dan Terapi. Jakarta: RajaGrafindo Persada.

Muhaimin, (2001) Paradigma Pendidikan Islam: Upaya Mengefektifkan Pendidikan Agama Islam di Sekolah. Bandung, Remaja Rosdakarya.

Mulyasa, E. (20150 Guru dalam Implementasi Kurikulum 2013. Bandung: Rosdakarya.

Mulyasa, E. (2007) Kurikulum Tingkat Satuan Pendidikan. Bandung: Remaja Rosda Karya.

Nata, Abuddin. Pemikiran Para Tokoh Pendidikan Islam, Seri Kajian Filsafat Pendidikan Islam. Jakarta: Raja Grafindo Persada, 2001.

Nata, Abuddin. (2012) Tafsir Ayat-Ayat Pendidikan. Jakarta: Rajawali Pers.

Sukanda, Agus S. (2011) Akhlaq Lingkungan, Panduan Berperilaku Ramah Lingkungan. (Yogyakarta: KNLH RI dan LLH PP Muhammadiyah.

Supriadi, Dedi. (2005) Membangun Bangsa Melalui Pendidikan. Bandung: Remaja Rosdakarya.

Supriadi. Pelaksanaan Pembelajaran Pendidikan Agama Islam Berbasis Lingkungan Alam Sekitar di SDIT Sahabat Alam Palangka Raya. Dosen Fakultas Agama Islam Universitas Muhammadiyah Palangkaraya, 2015.

Suryosubroto. Pembelajaran di Sekolah. Jakarta: Rineka Cipta, 2002.

Susapti, P. Pembelajaran Biologi Berbasis Lingkungan di MI. Workshop Internasional Pendidikan Sains Berbasis Lingkungan yang diselenggarakan oleh Sekolah Tinggi Agama Islam Negeri (STAIN) Salatiga pada tanggal 6-8 Agustus 2009.

Susilawati,Ulfa. (2011) Menanamkan Etika Lingkungan Hidup dalam Bingkai Pendidikan Islam,dalam Hamam (editor), Madrasah dan Pelestarian Lingkungan Sumbangan Konseptual dan Strategi Aksi, Salatiga: STAIN Salatiga Press. 